DOI: $10.21802 / \operatorname{artm} .2021 .4 .20 .124$

UDC $378.147+614.253 .1+616.314$

\title{
MOTIVATION PECULIARITIES OF DENTISTS' CONTINUOUS PROFESSIONAL DEVELOPMENT
}

\author{
A.B. Kostyshyn ${ }^{1}$, Z.T. Kostyshyn ${ }^{2}$, U.R. Lukach ${ }^{4}$, O.G. Boychuk-Tovsta ${ }^{2}$, O.M. Repetska ${ }^{2}$, O.V. Panchak ${ }^{3}$ \\ Ivano-Frankivsk National Medical University: \\ ${ }^{1}$ Department of Orthopedic Dentistry, \\ ORCID ID: 0000-0001-5500-08742; \\ ${ }^{2}$ Department of Dentistry of Postgraduate Education, \\ ORCID ID: 0000-0002-1840-8317, \\ ORCID ID: 0000-0002-7858-5884, \\ ORCID ID: 0000-0003-2880-9971; \\ ${ }^{3}$ Department of Psychiatry, Addiction and Medical Psychology, \\ ORCID ID: 0000-0001-5030-3622, Ivano-Frankivsk, Ukraine; \\ ${ }^{4}$ Ivano-Frankivsk Regional Institute of Postgraduate Pedagogical Education, Department of Management and \\ Educational Innovations, Ivano-Frankivsk, Ukraine, ORCID ID: 0000-0002-2229-0315
}

Abstract. One of the main tasks of modern higher education is to train specialists with a high level of competence who can constantly work on themselves.

The relevance of the research topic is due to the need for continuous professional development of future dentists and the motivation of their training, and the development of an active life position in modern society.

The purpose of our work is to study aspiration peculiarities of IFNMU students and interns to the successful and versatile improvement of personality.

The personal qualities of the doctor provide comfortable psychological contact with the patient and maintain professional activities dedication. Communicative competence is the subject of special research in the field of future doctors' training. Professional communication is considered to be one of the components of the general culture of relations and contributes to the successful career of a specialist in any sphere of activity, especially the medical one.

The problem of forming and maintaining educational interest to master the future specialty of students and interns continues to exist. Motivational components and factors that affect the professional and personal development of the future doctor increase with each year of study, and this process should not stop for life. It's effectiveness depends on the forms of the material presentation.

The presence or absence of positive motives in students and interns have a significant impact on educational activities. Insufficient motivation cannot contribute to the formation of their high professional realization. Therefore, a genuine and persistent desire to acquire knowledge and skills should be the starting point in the formation of a highly qualified healthcare professional.

The main factor influencing the interest in the education of students and interns is the acquisition of knowledge, skills, and abilities, which will form the foundation of professional activity in the future. The following factors contribute to increase the motivation of learning: the method of learning the material, its content, teaching methods; usage of problem tasks at each stage of the class; application of interactive technologies.

Our analysis showed that gaining knowledge among students and interns is dominated by professional motives: to become a highly qualified dentist and to find a job that meets personal desires in the occupation of their choice.

Thus, learning is more effective when it is motivated, and the activities of students coincide in direction and purpose. As a result, the graduate's professional training becomes successful.

The effectiveness of the educational process depends on the variety of forms and methods of presenting scientific and practical material. The directions of increasing motivation are as follows: constant improvement and updating of material, the use of interdisciplinary links to understand the importance and practical necessity of each subject in a higher educational establishment, the use of multimedia presentations during practical and lecture classes, work in simulation centers, implementation in the educational process of situational tasks "patient-doctor and doctor-patient" with further discussion and recognition of the flaws of each participants' work.

The usage of the latest information technologies and simulation centers helps not only to memorize a large amount of theoretical material but also to obtain practical and communication skills which are necessary for a modern doctor.

Keywords: motivation, continuous professional development.

Introduction. Motivation is of exceptional interest to all people, especially in the pedagogical process as it is a leading factor in regulating the activity of the individual, their behavior, and activities.

The motivation of future doctors' educational activity becomes one of the priority problems during the 
modern transformations in Ukrainian education. Today it is fundamental in psychological and pedagogical science. Thus it requires new approaches to the organization of university students.

Today the teacher's activities have become more complex. The methods of stimulation and even a big rating encouraging do not always lead to the goal, so it is necessary to use more effective technologies. One of these is the motivation of educational activities [1].

Acquiring a profession is not just a process of mastering a general or personal skills, but also a successful systematic process of mastering a certain range of knowledge and skills.

In the "Short Dictionary of Foreign Words" [2], the concept of "learning motivation" is interpreted as a set of external motivations, individual aspirations, and rational arguments that determine a person's decision to continue learning activities. It is a personified process of internal readiness formation for making such a decision. This decision is connected with the social circumstances and personal qualities, which determine and stimulate the cognitive activity of a person.

There are several types of motivation. In particular, learning that is consciously carried out by a person is both the result of processing the influence that they receive from the family and social environment and education, attitude to these influences associated with the peculiarities of life attitudes, aspirations, human interests. All these factors affect their character because unmotivated, as well as an unfocused activity simply does not exist.

One of the effective technologies during working with educational activity motivation of students and interns is defining their cognitive and social needs and their ways of satisfaction.

While working with students, the teacher determines their sense of purpose, tries to activate and change it according to the social needs of the country.

The relevance of the research topic is due to the need for continuous professional development of both students and doctors, the motivation of their learning, and the development of an active life position in modern society.

Motivation includes several factors that define the activity of the individual, namely motives, incentives, situational factors, needs that determine human behavior. This sphere of any activity performs various functions, such as: motivating (causes human activity); guiding (determines the nature of the goal in it); regulatory (specifies the value orientations, motives).

There are motivational theories, in which the basic are physiological needs, the need to implement them in safety, aspirations for communication, friendship, love, and self-esteem are also important. The highest level of the needs pyramid is the desire for self-actualization.

The motivation of youth learning activities is an essential condition for the effective educational process, as a negative or indifferent attitude to learning can be the cause of low success or failure of the student.

The main factor influencing students and interns is the desire to acquire knowledge, skills, and abilities, which will further form the foundation of a professional occupation. Young people interested in academic activity have self-development motives, which make you work hard, solve difficult problems, engage in self-education, and overcome difficulties to achieve the highest results.

Unfortunately, both students, interns, and teachers make mistakes during the learning process. In particular, when motivating, mentors try to give the maximum amount of knowledge without justifying its need. However, it is advisable to explain the future necessity of this knowledge because otherwise, a student will lose interest to study the subject.

It is necessary to say that the internal and external interests of a young person are interrelated, as it is a part of the same process. Increasing internal motivation is positively reflected in external motives and ultimately nurtures a strong professionally focused personality. Improvement of higher medical education according to modern requirements is impossible without the introduction into the teacher's methodological arsenal of the latest pedagogical and information technologies, new teaching methods, and original methodological techniques [3].

Motivation begins in school when choosing a profession. One of the reasons for the low quality of education, as noted in the concept of "New Ukrainian School", is that "Ukrainian students receive a lot of knowledge in school," and students often do not know how to use them to solve life problems. Today the theoretical component dominates over the practical one, and profession choice is usually done by graduates with parents. So most often it depends on the number of points scored during the external independent evaluation and career guidance [4].

The formation of the student's educational activity motives structure begins from the first days in a higher education institution, but the effectiveness of such a process may differ. It mainly depends on how successfully and quickly yesterday's entrant adapts, overcomes the difficulties they inevitably encounter, getting into an unusual environment for them.

If the motivation is low, teachers have to use different ways to stimulate learning. As young people enter medical school to become good specialists in medicine, the teacher must prove that his subject will be necessary for further professional occupation. In addition, it is essential not only to evoke interest in the subject but also to open for students or interns opportunities for practical application of the acquired knowledge. It is important for a young person to see a teacher as his mentor, to be able to turn to him for help during the learning process, and to discuss complex issues. It is relevant to respect students and interns in order to increase motivation to study.

Therefore, a special role in this process is played by the type of teacher. Type 1 is a teacher-tyrant, who requires obedience, and for whom the power is significant. Type 2 is a teacher-computer, a person who requires knowing information, facts, and knowledge. Type 3 is a teacher-martyr, for whom the most important thing is a conflict-free environment, who expects obedience, and wants to serve others. Type 4 is a teacher-friend, for whom popularity is relevant, a lenient friend, always ready to forgive, and requires a good attitude. But there is another position - partnership, where the teacher knows that they cannot, have no right to assert themselves at the expense of others but on the contrary, to be a leader, to teach future 
professionals to remain human in any situation.

However, some teachers consider their students or interns to be lazy, although they may simply not understand the topic. So communication should not be formal, superficial, or manipulative. It should be based on a deep interest in students, and recognition of the independence of their personalities.

At the same time, the contradiction between the theoretical and practical components of education cannot be resolved in an instant. The dominance of theoretical or practical components of education depends on age, the content of the subject, and future professional choice.

The application of knowledge as an important practical component of education can be abstract and vital. Therefore, it is necessary to direct the practical component of subjects to solve important daily problems.

The didactic innovativeness of higher education is the use of other, different from school, forms and methods of organizing the educational process, including the submission of new material, reporting, and control. Future doctors are obliged to show much greater independence, to practice time management, to organize work optimally in the process of setting educational goals. However, not everyone can do it quickly. The effectiveness of the educational process is directly related to how high the incentive to master the future profession is.

Motivation is a complex process with incentive factors in different directions: external - depends on the environment: parents, teachers, society, and internal reflects a person's personality, desires, strength of spirit, perseverance. The development of personal motivation is the most important, and it is prior in the process of becoming a specialist, especially a physician.

At the same time, motivation is a rather complex process that can have different directions: internal is personal and more meaningful, effective, and necessary form, and external - comes from parents, teachers, society.

The problem of motivating educational activity is not to force a student or intern to do "like everyone else" but to find technologies that meet the social order of society - the preparation of a graduate of a higher education institution competitive in the labor market. Recognizing the value of education, modern society questions the content of educational programs. Very often we hear opinions about the needlessness of some topics, sections, and even disciplines. This is a fairly simplistic approach.

The way of mastering the educational material helps to increase the motivation of educational activity. Usually, the subject is learned as a sequence of individual phenomena, each of which the teacher explains sequentially, giving a ready-made algorithm for dealing with them. The young man has no choice but to memorize the algorithm and act accordingly. At such mastering of a subject, there is a danger to lose interest in it.

On the contrary, when the study of the subject is carried out through the disclosure of the essence that underlies all phenomena, and based on which you can learn individual phenomena, then the learning activity becomes creative, thereby arousing interest in the subject. At the same time, both its content and the method of working with it can motivate a positive attitude to study this subject.

Relevant in learning interest is the relationship between motive and purpose. The goal set by the teacher must be clear and personal. To turn the goal into motives, it is significant to become aware of the need to master the specialty by the future doctor.

At each stage of the class, it is necessary to use problem tasks. If the teacher does this, then, usually, the motivation is at a high level. It is important to note that in content it is cognitive, that is to say internal.

Negative factors of the educational process motivation, which do not contribute to the interest in learning, are as follows: insufficient use of modern technologies in the pedagogical process, a large amount of information needed for daily processing to prepare for various subjects. In addition, according to the survey, the lack of free time and large amounts of homework negatively affect motivation.

At the same time, the availability and accessibility of educational and methodological support contribute to the improvement of independent work of students or interns. The use of interactive technologies increases their learning interest, forms the ability to analyze the data obtained, and to apply knowledge in practice.

The most effective technology for ensuring the success of students is the procedural theory of expectations. Concerning motivation for learning, this theory highlights the importance of the following relationships: a balanced relationship between effort and results; expectation of a certain reward or encouragement in response to the achieved level of results and the expected degree of satisfaction. According to this theory, if the value of any of these factors is small, then the motivation of educational activities, in general, will be weak. That is why it is necessary to pay attention to the meaningfulness of future doctors' work while studying the material, the degree of their activity, independence of tasks, attitude to personal results, the ability to work in groups, respond to recognition and encouragement, and the ability to obtain necessary information. As a result, the teacher gets a certain picture of their interest, problem areas become apparent, and it is possible to identify ways to change the situation to increase the motivation of educational activities.

The problem of interest in knowledge acquisition by medical students in Ukraine is quite acute, especially during modern reforms [5]. The results of the survey prove the existence of the problem, and therefore there is the need to find the solution. Studies of the dynamics of motivational processes in different medical universities note that the dynamics of professional development change during training. The frequency of high-level motivation in students increases during the last years of studying compared to the first ones. The obtained data are explained by the responsibility and confidence of most future doctors in the right choice of specialty.

We analyzed the research results of the motives for obtaining a profession in Ukrainian medical universities of students of different years of study and identified that medical students have 5 main motives for educational activities: the first one - to become a highly qualified specialist (36.4\%), the second - to acquire deep 
knowledge in medicine (34\%), the third - to ensure the success of future professional activity $(18.2 \%)$, the fourth - to get intellectual pleasure from learning $(6.8 \%)$, the fifth - to study well, to pass exams for "good" and "excellent" marks $(4.5 \%)$. In addition, most of the surveyed students highlight the positive motivational aspect of receiving praise from colleagues and teachers [6].

At the same time, researching the motivation of IFNMU interns in the "Dentistry" specialty we found that the main priorities for them are as follows: to become a highly qualified specialist, to find a job in a specialty that meets personal desires, and then - successfully pass the final exam, and obtain a specialist certificate. Unlike students, they do not pay much attention to the respect of teachers, the approval of parents, and others. Of great motivational importance is staffing students or interns in small groups, so at the Department of Dentistry, interns study in groups of 5-6 people.

One of the significant features of a modern person is the perception of information through short, vivid links, embodied in the format of a poster, video clip. The ability to quickly switch between different fragments of information and qualitatively process it has been studied. It is known that the supply of figurative, non-textual information accelerates its assimilation and allows to keep the brain in random access memory. Therefore, multimedia presentations are an appropriate addition to both practical and lecture classes.

Another sphere of modern technologies usage is the establishment of simulation centers based on medical higher educational institutions. Simulation education is widely used in the practical training of medical professionals and has proven to be an effective method of teaching. Thanks to the technical means of education, the necessary conditions are created for the development and consolidation of practical skills, and their practice is as close as possible to reality. The simulation method gives the future doctor the opportunity to be in different roles while performing professional tasks. Students and interns develop communication skills with the patient, they work in a team and take responsibility in the decision-making process. The game "doctor-patient and patient-doctor" is an effective pedagogical innovative learning tool. It aims to form clinical thinking in a specially created problem situation. This approach allows everyone to try themselves in different roles, promotes the use and consolidation of interdisciplinary links in practice, and allows to feel the responsibility of being a doctor while making independent decisions. The simulation method is one of the interactive methods of scientific and practical education. This method brings diversity to the educational process, provides an opportunity to cope with real situations that occur in professional life, thereby adapting to work and establishing social contacts.

Conclusions: The analysis showed that among students and interns, the main reason for high motivation to acquire knowledge is the prospect of becoming a qualified specialist.

Therefore, learning is more effective when it is motivated and when the activities of students coincide in direction and purpose.

The effectiveness of the educational process depends on the variety of forms and methods of presenting scientific and practical material. The directions of increasing motivation are as follows: constant improvement and updating of material, the use of interdisciplinary links to understand the importance and practical necessity of each subject in a higher educational establishment, the use of multimedia presentations during practical and lecture classes, work in simulation centers, implementation in the educational process of situational tasks "patient-doctor and doctor-patient" with further discussion and recognition of the flaws of each participants' work.

At the same time, the usage of the latest information technologies and simulation centers helps not only to memorize a large amount of theoretical material but also to obtain practical and communication skills which are necessary for a modern doctor.

\section{References:}

1. Kovalenko NP, Bobrova NO, Gancho OV, Zachepylo $\mathrm{SV}$. The motivation of students as a guarantee of successful professional development. Medical education. 2020; 3:43-48. DOI: 10.11603/me.24145998.2020.3.11440.

2. Kovalenko NP, Ponomarenko SV, Pospelova GD, Sherstyuk OL Motivation of educational activity as a guarantee of successful professional training of the student. A modern approach to teaching disciplines in the context of improving the quality of higher education. Materials of the 50th scientific methodological conference of teachers and graduate students. Poltava. 2019; February, 26-27:13-16.

3. Baranova IV, Ilyuk IA, Postovitenko KP. Motivation to study - the key to the effectiveness of modern medical education. Medical education. 2019; 2:55-60. DOI: 10.11603/me.2414-5998.2019.2.10344.

4. Kostyshyn AB. Professional higher education - the basis of quality higher education. Art of Medicine. 2020; 4(16):114-119. DOI: 10.21802/artm.2020.4.16.114. DOI: 10.21802/artm.2020.4.16.114.

5. Musyla IP, Zyatkovska OY, Bakalyuk TG. Teaching experience of English-speaking students at the Department of Medical Rehabilitation by the creditmodule system. Medical education. 2018; 1:95-97. DOI: 10.11603/me.2414-5998.2018.1.8837.

6. Venger OP, Guseva TP, Musyla YI, Sas LM. The motivation of achievement as a significant factor in the successful professional development of medical students. Medical education. 2018; 4:31-35. DOI: 10.11603/me.2414-5998.2018.4.9388.

\section{УДК $378.147+614.253 .1+616.314$ \\ ОСОБЛИВОСТІ МОТИВАЦІЇ БЕЗПЕРЕРВНОГО ПРОФЕСІЙНОГО РОЗВИТКУ ЛІКАРІВ-СТОМАТОЛОГІВ}

А.Б. Костишин ${ }^{1}$, 3.Т. Костишин ${ }^{2}$, У.Р. Лукач ${ }^{4}$, О.Г. Бойчук-Товста 2 , О.М. Репецька ${ }^{2}$ О.В. Панчак ${ }^{3}$
Івано-Франківський національний медичний університет:
${ }^{1}$ кафедра ортопедичної стоматологї, ORCID ID: 0000-0001-5500-0874;
${ }^{2}$ кафедра стоматологї післядипломної освіти, ORCID ID: 0000-0002-1840-8317,
ORCID ID: 0000-0002-7858-5884, 
ORCID ID: 0000-0003-2880-9971;

${ }^{3}$ кафедра психіатрії, наркології та медичної

психологіï,

ORCID ID: 0000-0001-5030-3622,

м. Івано-Франківськ, Украӥна;

${ }^{4}$ Івано-Франківський обласний інститут післядипломної педагогічної освіти, кафедра менеджменту та освітніх інноващій, м. Івано-Франківськ, Украӥна,

ORCID ID: 0000-0002-2229-0315

Резюме. Одним із ключових завдань сучасної вищої освіти є підготовка спеціалістів із високим рівнем компетентності, які здатні постійно працювати над собою.

Актуальність теми дослідження зумовлена необхідністю безперервного професійного розвитку майбутніх стоматологів та мотивацією їх навчання, розвитком активної життєвої позиції в умовах сучасного суспільства.

Мета - це вивчення особливостей прагнень студентів та лікарів-інтернів ІФНМУ до успішного різнобічного вдосконалення особистості.

Проблема формування та підтримки зацікавленості навчанням при опануванні молоддю майбутньої спеціальності продовжує існувати. Мотиваційні складові та фактори, які впливають на фаховий та особистий розвиток майбутнього лікаря, зростають із кожним курсом навчання, та цей процес не повинен зупинятися упродовж всього життя. Його ефективність залежить від форм подання матеріалу.

Основним фактором, що впливає на зацікавленість освітою студентів й інтернів, є оволодіння знаннями, уміннями та навичками, які в подальшому сформують фундамент професійної діяльності. Підвищенню мотивації навчання сприяють: спосіб засвоєння матеріалу, його зміст, методи викладання; використання на кожному з етапів заняття проблемних завдань; застосування інтерактивних технологій.

Проведений нами аналіз показав, що при отриманні знань серед студентів та лікарів-інтернів стоматологів переважають професійні мотиви: стати висококваліфікованим лікарем-стоматологом та знайти добру роботу зі спеціальності, що відповідає особистим бажанням.

Таким чином, навчання ефективніше, коли воно мотивоване, а діяльність здобувачів освіти збігається за спрямованістю та метою. У результаті професійна підготовка випускника стає успішною.

Ключові слова: мотивація, безперервний професійний розвиток.

\section{УДК 378.147+614.253.1+616.314 \\ ОСОБЕННОСТИ МОТИВАЦИИ НЕПРЕРЫВНОГО ПРОФЕССИОНАЛЬНОГО РАЗВИТИЯ ВРАЧА-СТОМАТОЛОГА}

А.Б. Костышин ${ }^{1}$, 3.Т. Костышин ${ }^{2}$, У.Р. Лукач ${ }^{4}$, О.Г. Бойчук-Товста ${ }^{2}$ О.М. Репецкая ${ }^{2}$, О.В. Панчак ${ }^{3}$

Иван-Франковский нацииональный медицинский университет:

${ }^{1}$ кафедра ортопедической стоматологии, ORCID ID: 0000-0001-5500-0874;

${ }^{2}$ кафедра стоматологии последипломного образования,

ORCID ID: 0000-0002-1840-8317,

ORCID ID: 0000-0002-7858-5884,

ORCID ID: 0000-0003-2880-9971;

${ }^{3}$ кафедра психиатрии, наркологии и медиичнской психологии,

ORCID ID: 0000-0001-5030-3622,

2. Ивано-Франковск, Украина;

${ }^{4}$ Ивано-Франковский областной институт последипломного педагогического образования, кафедра менеджмента и образовательных инноваций, г. Ивано-Франковск, Украина, ORCID ID: 0000-0002-2229-0315

Резюме. Одной из ключевых задач современного высшего образования является подготовка специалистов с высоким уровнем профессиональной компетентности, которые способны к постоянной работе.

Актуальность темы исследования обусловлена необходимостью непрерывного профессионального развития будущих стоматологов и мотивацией их обучения, развитием активной жизненной позиции в условиях современного общества.

Цель - это изучение особенностей стремлений студентов и врачей-интернов ИФНМУ к успешному разностороннему профессиональному совершенствованию личности.

Проблема формирования и поддержки интереса к обучению будущей специальности у молодежи продолжает существовать. Мотивационные составляющие и факторы, влияющие на профессиональное и личное развитие будущего врача, растут с каждым курсом обучения, и этот процесс не должен останавливаться в течение всей жизни.

Основным фактором, влияющим на заинтересованность образованием молодежи, является овладение знаниями, умениями и навыками, которые в дальнейшем сформируют фундамент профессиональной деятельности. Повышению мотивации обучения способствуют способ усвоения материала, его содержание, методы преподавания; применение интерактивных технологий.

Проведенный нами анализ показал, что при получении знаний среди студентов и врачей-интернов стоматологов преобладают профессиональные мотивы: стать высококвалифицированным врачом-стоматологом и получить хорошую работу по специальности, соответствующую собственному желанию.

Таким образом, обучение эффективнее, когда оно мотивировано, а деятельность соискателей образования совпадает по направлению и цели. В результате профессиональная подготовка выпускника становится успешной.

Ключевые слова: мотивация, непрерывное профессиональное развитие.

Стаття надійшла в редакцію 03.11.2021 р. Стаття прийнята до друку 12.12. 2021 р. 